\title{
腰部疾患に伴う下垂足の予後調査
}

\author{
長崎三菱病院整形外科 \\ 米 倉 暁 彦・瀬 良 敬 祐 \\ 宮 原 健 次. 原真一郎
}

\section{Follow-up Study of Foot Drop Associated with Lumbar Disorders}

by

\author{
Akihiko Yonekura, Keisuke Sera, Kenji Miyahara \\ and Shinichiro Hara \\ Department of Orthopaedic Surgery, Nagasaki Mitsubishi Hospital
}

\begin{abstract}
Fifteen cases of foot drop associated with lumbar disorders were investigated to identify the factors influencing clinical results.

Fifteen surgically treated cases, ( 9 males and 6 females) were followed up for an average period of 2 years and 7 months. The mean age at the time of operation was 54.1 years. Patients consisted of 10 cases of herniation of the nucleus pulposus (HNP), 4 cases with a combination of degenerative lumbar canal stenosis and HNP (combined stenosis), and one case of postoperative extradural hematoma. The results were evaluated using six grades of the tibialis anterior muscle strength with manual muscle testing (MMT). We considered the patients who were grade 4 or 5 by MMT to be recovered, the other 8 patients were judged to be not recovered. Results were compared and analyzed with reference to age, type of onset of foot drop, weakness of tibialis anterior muscle before surgery, type of lumbar disorder and the interval between onset of foot drop and surgery.

In this series, older patients tended not to recover. Patients whose foot drop had appeared gradually and/or whose muscular contraction was weak did not recover. Foot drop did not improve in the cases of combined stenosis, and patients who had surgery 3 weeks or more after onset did not recover.
\end{abstract}

Key words : drop foot (下垂足), herniation of the nucleus pulposus (腰部椎間板ヘルニア), lumbar canal stenosis（腰部脊柱管狭窄症）

\section{はじめに}

種々の腰部疾患で下垂足を生じる頻度は 4 から $6 \%$ と報告されている(1)5)6) がこれらの予後を原疾患の治 療前に予測することは必ずしも容易ではない。それは 下垂足の発生や回復がいくつかの因子に左右されてい るからである. 本研究の目的は腰部疾患に伴う下垂足 の回復に影響を与える因子を明らかにすることである.

\section{対象および方法}

過去 12 年間に当院で観血的治療を行った腰部疾患
691 例中術前の足関節背屈筋力が 2 以下であった症例 は 17 例で, その頻度は $2.5 \%$ であった。このうち下 垂足が神経根の急激な圧迫によって生じたと考えられ る 15 例（男性 9 例, 女性 6 例）を今回の調查の対象 とした. 右側罪患が 8 例で, 左側が 4 例で, 両側が 3 例である. 手術時年齢は 31 歳から 71 歳（平均 54.1 \pm 11.3 歳), 術後の経過観察期間は 3 ケ月から 11 年 7 ケ月（平均 2 年 7 ケ月 \pm 2 年 9 ケ月）である.

前脛骨筋の筋力を徒手筋力テストで判定した. 術前 は 0 が 4 例, 1 が 7 例, 2 が 4 例であり, 調查時は 0 が 2 例, 2 が 4 例, 3 が 2 例, 4 が 1 例, 5 が 6 例で 
あった.この調査時の筋力が 4 以上の症例を回復群 $(\mathrm{n}=7), 3$ 以下の症例を非回復群 $(\mathrm{n}=8)$ とし, この両群と手術時年齢, 下垂足の起こり方, 術前の筋 力, 脊髄腔造影所見, 下垂足出現から手術までの期間, 原因疾患および障害神経根との関係を調べた。なお， 有意差判定には主に $\mathrm{t}$ 検定と $\chi^{2}$ 検定を用い, 有意確 率が $0.05 \%$ 末満を有意差ありとした。

\section{結果}

手術時年齢は回復群が平均 $50.1 \pm 13.6$ 歳, 非回復 群が $57.5 \pm 9.4$ 歳であり, 両者の間に有意差はなかっ た.しかし年㱓別にみると 49 歳以下の回復率は 5 例 中 $20 \%, 50$ 歳以上では 10 例中 $70 \%$ で 50 歳を境にし て明らかな差がみられた（図 1 )。

下垂足が下肢筋力低下から 7 日以内に完成したもの を急激例，それ以上の日数を要したものを緩徐例とす ると前者は 13 例, 後者は 2 例であった。この下垂足 の起こり方と回復状況の関係をみてみると, 回復群は 全症例が急激に起こっており, 非回復群は急激に起こっ た症例が 6 例で緩徐に起こった症例が 2 例であった。 下垂足が緩徐に起こった症例はすべて非回復群であっ た（表 1 ).

術前の筋力の程度と回復状況との関係では, 術前の 前脛骨筋筋力が 0 であった 4 例は全例回復しなかった. 症例数 (例)

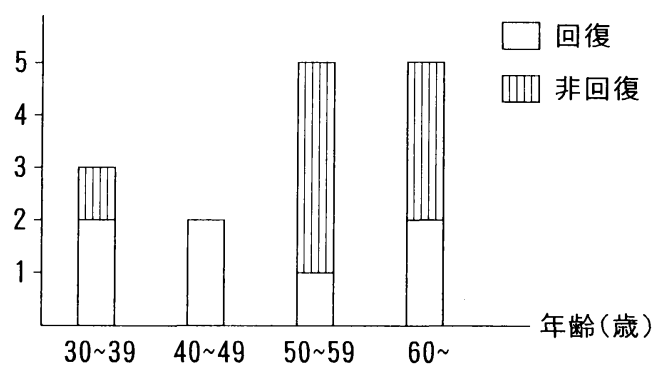

図 1 手術時年齢と回復状況 手術時年齢が 50 歳以上の症例では非回復例の 割合が高くなっている.

表 1 下垂足の起こり方と回復状況

\begin{tabular}{|c|c|c|c|}
\hline & & 回 復 & 非 回 復 \\
\hline 下垂足の & 急激 $(n=13)$ & 7 & 6 \\
\hline 起こり方 & 緩徐 $(n=2)$ & 0 & 2 \\
\hline
\end{tabular}

1 であった 7 例中 5 例と 2 であった 4 例中 2 例は回復 した（表 2 ).

脊髄腔造影の正面像を神経根の欠損のみのもの（1 型), 硬膜柱の一部まで欠損するもの ( 2 型), 不完全 または完全ブロックを呈するもの（ 3 型）に分類した. そしてこれら造影所見と回復状況との関係を調べた. 1 型であった 4 例のうちの 1 例, 2 型の 4 例中 2 例, 3 型の 6 例中 3 例が回復していた（表 3 ).

下垂足出現から手術までの期間を $0 \sim 7$ 日， 8〜14 日，15〜21 日および 22 日以上に分類して回復状況を 比較した. その結果 22 日以上の 3 割は全例非回復群 であった。しかし 21 日以下の症例では回復群および 非回復群の間で手術までの期間に有意差はみられなかっ た（図 2 ).

手術所見より確定した原因疾患は腰部椎間板へル ニア10例, 腰部手術後硬膜外血腫 1 例, combined stenosis 4 例であった。 これらと下垂足の回復状況の 関係は腰部椎間板ヘルニアの 6 例と硬膜外血腫の 1 例 は回復したが, combined stenosis は全例回復しな

表 2 術前前脛骨筋筋力と回復状況

\begin{tabular}{ll|cc}
\hline \hline & & 回 復 & 非回 復 \\
\hline & $0(\mathrm{n}=4)$ & 0 & 4 \\
術 前筋力 & $1(n=7)$ & 5 & 2 \\
& $2(n=4)$ & 2 & 2 \\
\hline
\end{tabular}

表 3 脊䯣腔造影所見と回復状況

\begin{tabular}{ll|cc}
\hline \hline & & 回 復 & 非回 復 \\
\hline & 1 型 $(n=4)$ & 1 & 3 \\
脊髄腔造影 & 2 型 $(n=4)$ & 2 & 2 \\
& 3 型 $(n=6)$ & 3 & 3 \\
\hline
\end{tabular}

症例数 (例)

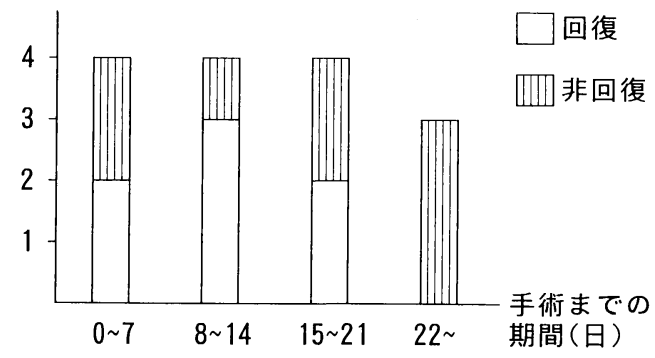

図 2 下垂足出現から手術までの期間と回復状況 手術までの期間が 22 日以上経過した症例では 下垂足の回復はみられなかった。 
表 4 原因疾患と回復状況

\begin{tabular}{ll|cc}
\hline & & 回 復 & 非 回 復 \\
\hline 腰部椎間板ヘルニア $(\mathrm{n}=10)$ & 6 & 4 \\
術後硬膜外血腫 & $(\mathrm{n}=1)$ & 1 & 0 \\
combined stenosis $\quad(\mathrm{n}=4)$ & 0 & 4 \\
\hline \multicolumn{3}{c}{} \\
\multicolumn{3}{c}{ 表 5 } & ヘルニア形態と回復状況 \\
\hline \hline protrusion & $(\mathrm{n}=3)$ & 1 & 2 \\
prolapse & $(\mathrm{n}=3)$ & 1 & 2 \\
extrusion & $(\mathrm{n}=4)$ & 2 & 2 \\
sequestration & $(\mathrm{n}=4)$ & 2 & 2 \\
\hline
\end{tabular}

表 6 障害神経根と回復状況

\begin{tabular}{|c|c|c|c|}
\hline & & 回 復 & 非回復 \\
\hline & $(\mathrm{n}=3)$ & 1 & 2 \\
\hline 障 害 & $(\mathrm{n}=4)$ & 2 & 2 \\
\hline \multirow[t]{2}{*}{ 神経根 } & $\mathrm{L} 4+\mathrm{L} 5+\mathrm{S} 1(\mathrm{n}=3)$ & 1 & 2 \\
\hline & $(\mathrm{n}=4)$ & 2 & 2 \\
\hline
\end{tabular}

かった（表 4 )。ヘルニアの形態別にみると回復群は protrusion が 1 例, prolapse が 1 例, extrusion が2 例, sequestration が2 例であり, 非回復群はそ れぞれ 2 例ずつであり下垂足回復との関連はなかった (表 5 ).

障害神経根の組み合わせは 4 つのタイプにわけられ た、いずれも L5 神経根の障害を認めたが回復群, 非 回復群それぞれに特徴的な型は示さなかった（表 6 ）.

\section{考察}

腰部疾患に伴う下垂足の回復を不良にする因子とし て中年, 術前前脛骨筋筋力が 0 , 複数根の障害, 下垂 足出現から手術までの期間が長い症例，combined stenosis 例, 膀胱直腸障害の存在が諸家により報告 されている(1)4/5)6). 今回の我々の調査では手術時年齢, 下垂足の起こり方, 術前前脛骨筋筋力, 下垂足出現か ら手術までの期間および原因疾患が下垂足の回復に影 響を与えていた。手術時年齢に関しては高齢者の筋力 回復が悪く，これは変形性脊椎症性変化による神経根 の圧迫が基盤にあるため神経根の圧迫期間が長いこと， 及び手術による神経根除圧後の回復が若年者に比し悪 いことが原因として推測される。しかし対象例の中に は 64 歳及び 69 歳と高齢にも関わらず下垂足が回復し
ている例もあることから高齢のみで予後を云々するこ とはできないと思われる．下垂足の起こり方では下垂 足が緩徐に起こった症例は筋力回復がみられなかった。 これらの症例は全て後述する combined stenosis 例 であった．神経根の慢性圧迫により神経根に非可逆性 の変化が起こっていることを示すものである．術前前 脛骨筋筋力に関しては筋力が 0 であった症例の筋力回 復はみられず神経根の圧迫が高度であったことが推測 される，原因疾患に関しては combined stenosis 例 で下垂足は回復しなかった。これは高歯者の場合と同 様に神経根の圧迫期間が長いことが考えられる。下垂 足出現から手術までの期間に関しては発症から 1 ケ月 以内に手術した症例では回復群及び非回復群の間に手 術までの期間に有意差はなかった。しかし発症から 22 日以上経過した症例では下垂足の回復がみられなかっ たことから手術のタイミングとしては下垂足出現後早 期に手術すべきであると思われる。

\section{ま と め}

(1)腰部疾患が原因で生じた下垂足の 15 例について 筋力回復に影響を与える因子を調查した。

(2)手術時年齢，下垂足の起こり方，術前前脛骨筋筋 力，下垂足出現から手術までの期間および原因疾患は 下垂足の回復に影響を与えていた。

(3)特に下垂足が緩徐に起こった症例や術前前脛骨筋 筋力が 0 であった症例および combined stenosis 例 では下垂足は回復しなかった。

(4)脊靇道腔造影所見, ヘルニア形態求よび障害神経根 は下垂足の回復に影響を及ほしていなかった。

\section{参 考 文 献}

1）千葉英史：下垂足を伴う腰部神経根障害の検討。中部 整災誌, $34: 210-212,1991$.

2）工藤 修: 腰仙部神経根症状の多様性に関する解剖学 的考察. 整形外科, $35: 775-784,1984$.

3) McCulloch, J.A. and Waddel, G.: Variation of the lumbosacral myotomes with bony segmental anomalies. J.Bone and Joint Surg. 62-B : 475-480, 1980.

4）浪花紳悟：下垂足をきたした腰椎疾患. 西日本脊椎研 究会誌, $14: 73-78,1988$.

5）上田 淳：下垂足を伴う腰椎疾患の臨床的検討。整形 外科と災害外科, $39: 467-470,1990$.

6）山本利美雄 : 腰部椎間板へルニアによる下垂足. 臨整 外, $22: 445-452,1987$. 